\title{
PENGARUH KONSENTRASI LARUTAN DAUN CENGKEH TERHADAP JUMLAH LALAT HIJAU YANG HINGGAP SELAMA PROSES PENJEMURAN IKAN ASIN
}

\author{
Khonsa Abdullah S, Dindin Wahyudin \\ Poltekkes Kemenkes Bandung Jurusan Kesehatan Lingkungan \\ Jl. Babakan Loa-Gunung Batu, Cimahi Utara -Kota Cimahi \\ Email : din.wahyudin09@yahoo.com
}

\begin{abstract}
The effect of concentration solution leaf clovers (syzigium aromaticum) to total flies green (chrysomya megacephala) which perch in fish salted during drying process. The Food is anything that comes from biological sources and water, whether treated or untreated, which is applied as a food or beverage for human consumption. Almost $65 \%$ of fishery products in Indonesia is still processed by salting which produces salted fish products. The leaf clovers (Syzigium aromaticum) is one kind of plant that can be used as a natural insecticide reppelent vegetable because it contains an active substance that is believed Euganol not liked by the flies. The purpose of this research conducted to determine differences in various concentration of leaf clovers (Syzigium aromaticum) on the number of green flies (Chrysomya megacephala) that settle during the drying process of salted fish. Type of research was experimental design with posttest only control group design. The results of this study include the average number of flies alighted during the drying process anchovies ( 8 hours), using a concentration of $1.56 \%$ leaf clovers as many as eight tails, $3.12 \%$ concentration of 7 animals. $6.25 \%$ concentration of 4 tails, a concentration of $12.5 \%$ as much as 3 tails, a concentration of $25 \%$ by 2 tails, and a concentration of $50 \%$ as much as 1 tail. With a $\mathrm{P}$ value $(0.000)<\alpha$ confidence level of $95 \%$, or by comparing the value of $F(1363.000)>F$ table (4.06), then there is the influence of leaf clovers various concentration on the number of flies that settle during the drying process anchovies. The application of this method can be applied especially in an environment that produces the manufacture of salted fish. as a replacement for chemical insecticides to repel flies.
\end{abstract}

Keywords: Reppelent; Syzigium aromaticum; Chrysomya megacephala

\begin{abstract}
Abstrak: Pengaruh konsentrasi larutan daun cengkeh (syzigium aromaticum) terhadap jumlah lalat hijau (chrysomya megacephala) yang hinggap selama proses penjemuran ikan asin. Pangan adalah segala sesuatu yang berasal dari sumber hayati dan air, baik yang diolah maupun yang tidak diolah, yang diperuntukkan sebagai makanan atau minuman bagi konsumsi manusia. Hampir 65\% produk perikanan di Indonesia masih diolah dengan cara penggaraman yang menghasilkan produk ikan asin. Daun Cengkeh (Syzigium aromaticum) merupakan salah satu jenis tanaman insektisida alami yang dapat dijadikan Reppelent nabati karena memiliki kandungan zat aktif yaitu Euganol yang dipercaya tidak disenangi oleh lalat. Tujuan penelitian adalah untuk mengetahui perbedaan berbagai konsentrasi larutan daun cengkeh (Syzigium aromaticum) terhadap jumlah lalat hijau (Chrysomya megacephala) yang hinggap selama proses penjemuran ikan asin. Jenis penelitian adalah eksperimen dengan rancangan posttest only control group design. Hasil yang didapat dari penelitian ini diantaranya rata-rata jumlah lalat hinggap selama proses penjemuran ikan asin (8 jam), menggunakan konsentrasi larutan daun cengkeh 1,56\% sebanyak 8 ekor, konsentrasi 3,12\% sebanyak 7 ekor. konsentrasi 6,25\% sebanyak 4 ekor, konsentrasi 12,5\% sebanyak 3 ekor, konsentrasi 25\% sebanyak 2 ekor, dan konsentrasi 50\% sebanyak 1 ekor. Dengan nilai $\mathrm{P}(0,000)<\alpha$ tingkat kepercayaan 95\% atau dengan membandingkan nilai Fhitung $(1363,000)>$ nilai $\mathrm{F}$ tabel $(4,06)$, maka terdapat pengaruh berbagai konsentrasi larutan daun cengkeh terhadap jumlah lalat yang hinggap selama proses penjemuran ikan asin. Pengaplikasian metode ini dapat diterapkan khususnya di lingkungan yang memproduksi pembuatan ikan asin. sebagai pengganti insektisida kimia dalam mengusir lalat.
\end{abstract}

Kata kunci : Reppelent, Syzigium aromaticu;, Chrysomya megacephala 


\section{PENDAHULUAN}

Pangan adalah segala sesuatu yang berasal dari sumber hayati dan air, baik yang diolah maupun yang tidak diolah, yang diperuntukkan sebagai makanan atau minuman bagi konsumsi manusia. Termasuk didalamnya adalah tambahan pangan pangan, bahan baku pangan, dan bahan lain yang digunakan dalam penyiapan, pengolahan, dan atau pembuatan makanan atau minuman.

Risiko pangan terhadap manusia dapat timbul secara alami maupun terkait dengan penanganan pangan oleh manusia baik cemaran biologi, kimia atau fisik. Cemaran biologi umumnya ditemukan dalam bentuk bakteri Vibrio parahaemolyticus, Vibrio cholera, Salmonella, dan E.coli. Cemaran Kimia pada pangan karena terkontaminasi oleh logam berat (Mercury dan Timbal), Histamin (Pada ikan), Antibiotik, pestisida, formalin dan Rhodamin-B. Kerusakan makanan disebabkan oleh kerja mikroorganisme (bakteri, ragi dan jamur). Miroorganisme itu dapat menyebabkan busuk, proses ini dapat terjadi pada seluruh makanan.

Masalah pangan yang mencukupi dan bebas dari penyakit sudah menjadi pemikiran manusia sejak dulu, peningkatan derajat kesehatan tidak terlepas kaitannya dengan konsumsi bahan pangan yang berkualitas, bernilai gizi tinggi dan aman, yakni tidak terdapatnya benda asing yang dapat merusak kesehatan.

Indonesia merupakan penghasil produk perikanan yang cukup besar. Untuk pengolahannya sendiri lebih banyak dilakukan secara tradisional seperti penggaraman, pengeringan dan pengasapan dibandingkan dengan pengolahan modern seperti pembekuan dan pengalengan.

Hampir $65 \%$ produk perikanan di Indonesia masih diolah dengan cara penggaraman yang menghasilkan produk ikan asin. Tidak mengherankan apabila ikan asin termasuk dalam Sembilan bahan pokok penting bagi kebutuhan masyarakat ${ }^{(1)}$.

Salah satu proses penting yang dilakukan dalam pengolahan ikan asin adalah tahap penjemuran atau pengeringan(2). Menurut Kow dkk dalam Heruwati (2002)(2), proses pengeringan ikan asin memiliki potensi risiko pertumbuhan mikroorganisme akibat infestasi lalat. Penjemuran ikan asin yang dilakukan di udara terbuka dengan memanfaatkan sinar matahari, memungkinkan terjadinya serangan lalat yakni salah satunya adalah lalat hijau (Chrysoma megacephala).

Lalat memiliki bulu-bulu halus yang terdapat disekujur tubuhnya yang memungkinkan dapat berperan sebagai vektor penyakit, karena perilaku lalat yang suka berpindah-pindah dari suatu makanan (biasanya bahan organik yang membusuk ataupun kotoran) ke makanan lain untuk makan dan bertelur(3) .

Lalat rumah dapat menghasilkan telur 90-120 butir sedangkan lalat hijau menghasilkan 200-300 butir setiap kali bertelur. Selain menyebabkan kerusakan fisik, lalat juga menjadi perantara bagi kontaminasi bakteri pembusuk, patogen serta pembentuk racun seperti Acinetobacter, Staphylococcus, dan Vibrionaceae. Hasil pengamatan menunjukkan bahwa satu ekor lalat dapat membawa sekitar 102-103 bakteri pada musim kemarau dan antara 108-109 pada musim hujan. Untuk menanggulangi kerusakan akibat lalat selama penjemuran, pengolah ikan asin sering menggunakan insektisida sintetis yang disemprot secara langsung pada produk ikan(3).

Penggunaan insektisida sintetis yang tidak sesuai dengan fungsi dan ukurannya menimbulkan masalah berupa kandungan residu insektisida pada komoditi bahan pangan, yang pada akhir dapat membahayakan kesehatan masyarakat (3).

Residu insektisida yang terdapat dalam rantai makanan dapat memberikan dampak negatif terhadap manusia yakni menyebabkan keracunan bahkan kematian. Selain itu, berbagai penelitian menunjukkan bahwa pestisida dapat memberikan efek jangka panjang yakni menyebabkan kanker, gangguan kesehatan reproduksi pria dan wanita, kelainan syaraf, merusak sistem kekebalan tubuh, dan Parkinson(1).

Untuk mengurangi penggunaan insektisida sintetik perlu dikembangkan insektisida yang berasal dari alam dan penggunaannya aman bagi lingkungan maupun masyarakat. Insektisida nabati memiliki susunan molekul yang mudah 
terurai menjadi senyawa yang tidak membahayakan. Beberapa tanaman yang tergolong ke dalam tanaman aromatic seperti serai wangi, kayu putih, geranium, zodia, dan lainnya diyakini mempunyai khasiat mengusir lalat $(3)$.

Senyawa yang terkandung dalam tumbuhan dan berfungsi sebagai insektisida diantaranya adalah golongan sianida, saponin, tannin, flavanoid, alkaloid, steroid dan minyak atsiri(4).

Tanaman cengkeh diketahui mengandung minyak atsiri jenis eugenol yang aromanya diduga tidak disenangi lalat. Berdasarkan hasil penelitian di Balai Penelitian Tanaman Obat dan Aromatik (Balittro), produk cengkeh daun, gagang dan bunga dapat menekan bahkan mematikan pertumbuhan miselium jamur, koloni bakteri dan nematoda. Produk cengkeh bisa digunakan sebagai fungisida, bakterisida, nematisida, dan insektisida(2).

\section{BAHAN DAN CARA PENELITIAN}

Bahan-bahan yang digunakan yaitu, daun cengkeh, ikan deles dan lalat hijau (Chrysomya megacephala) sebagai subjek. Lalat hijau ditangkap dengan menggunakan fly-trap di tempat pembungan sampah sementra (TPS) terminal Cicaheum Bandung.

Kandang uji dengan ukuran $60 \mathrm{~cm} \mathrm{x}$ $60 \mathrm{~cm} \times 60 \mathrm{~cm}$ yang rangkanya terbuat dari kayu dan dindingnya dari kasa. Ikan deles dengan berat 100 gram dicuci, dibuang bagian dalamnya dan dibelah memanjang kemudian digarami.

Daun cengkeh diambil dari pohonnya, kemudian dicuci, diblender hingga halus. Daun cengkeh dilarutkan dengan aquades perbandingan (1:1) bagian kemudian didiamkan selama 24 jam. Setelah 24 jam larutan disaring dengan kain halus, seperti kain sifon yang merupakan sebagai larutan stok. Untuk membuat variasi konsentrasi larutan daun cengkeh untuk pengujian adalah dengan mengencerkan larutan stok yang telah dibuat dengan rumus $\mathrm{C}_{1} \mathrm{~V}_{1}=$ $\mathrm{C}_{2} \mathrm{~V}_{2}$.

Setelah semua bahan tersedia, penelitian dilakukan dengan cara; Chrysomya megacephala yang diperoleh dari TPS dimasukan ke dalam kandang uji, masing-masing sebanyak 100 ekor, kemudian di puasakan selama 24 jam supaya kondisinya sama. ikan deles yang sudah digarami (ikan asin), direndam dalam larutan daun cengkeh (Syzigium aromaticum) yang berbeda konsentrasi $(1,56 \%, 3,12 \%, 6,25 \%, 12,5 \%, 25 \%$ dan $50 \%$ ) masing-masing selama 30 detik. Ikan asin tersebut dimasukkan ke dalam kandang uji kemudian dijemur.

Proses penjemuran ikan asin dilakukan di tempat terbuka (outdoor) selama 10 jam mulai dari pukul 06.00 sampai dengan pukul 16.00 wib. Pengamatan dilakukan dengan cara menghitung jumlah lalat yang hinggap pada ikan asin setap 2 jam selama proses penjemuran.

\section{HASIL DAN PEMBAHASAN \\ Hasil}

Hasil pengamatan jumlah Chrysomya megacephala yang hinggap pada ikan asin selama proses penjemuran selama sehari, pada tanggal 27 Mei 2014.pengamatan dilakukan setiap 2 jam dari variasi konsentrasi larutan daun cengkeh (Syzigium aromaticum) diperoleh hasil sebagai berikut:

Tabel 1. Jumlah Chrysomya megacephala yang hinggap pada ikan asin selama proses penjemuran dengan berbagai konsentrasi larutan Syzigium aromaticum

\begin{tabular}{|c|c|c|c|c|c|c|c|}
\hline \multirow[t]{2}{*}{ Pengulangan } & \multirow[t]{2}{*}{$\begin{array}{l}\text { Konsentrasi } \\
\text { (\%) }\end{array}$} & \multicolumn{5}{|c|}{$\begin{array}{c}\text { Jumlah Chrysomya megacephala Yang Hinggap } \\
\text { Pada Jam }\end{array}$} & \multirow[t]{2}{*}{$\begin{array}{l}\text { Rata- } \\
\text { rata }\end{array}$} \\
\hline & & 08.00 & 10.00 & 12.00 & 14.00 & 16.00 & \\
\hline I & & $(100) 13$ & $(100) 10$ & $(100) 8$ & $(100) 6$ & $(100) 6$ & 9 \\
\hline II & 1,56 & $(100) 10$ & $(100) 8$ & $(100) 5$ & $(100) 6$ & $(100) 4$ & 7 \\
\hline III & & $(100) 18$ & $(100) 8$ & $(100) 6$ & $(100) 4$ & $(100) 6$ & 8 \\
\hline I & & $(100) 10$ & $(100) 6$ & $(100) 6$ & $(100) 4$ & $(100) 3$ & 6 \\
\hline II & 3,12 & $(100) 14$ & $(100) 8$ & $(100) 4$ & $(100) 2$ & $(100) 5$ & 7 \\
\hline III & & $(100) 15$ & $(100) 4$ & $(100) 4$ & $(100) 6$ & $(100) 7$ & 7 \\
\hline
\end{tabular}




\begin{tabular}{|c|c|c|c|c|c|c|c|}
\hline \multirow[t]{2}{*}{ Pengulangan } & \multirow[t]{2}{*}{$\begin{array}{l}\text { Konsentrasi } \\
\text { (\%) }\end{array}$} & \multicolumn{5}{|c|}{$\begin{array}{c}\text { Jumlah Chrysomya megacephala Yang Hinggap } \\
\text { Pada Jam }\end{array}$} & \multirow[t]{2}{*}{$\begin{array}{l}\text { Rata- } \\
\text { rata }\end{array}$} \\
\hline & & 08.00 & 10.00 & 12.00 & 14.00 & 16.00 & \\
\hline I & & $(100) 8$ & $(100) 6$ & $(100) 4$ & $(100) 3$ & $(100) 4$ & 5 \\
\hline II & 6,25 & $(100) 8$ & $(100) 6$ & $(100) 4$ & $(100) 2$ & $(100) 2$ & 4 \\
\hline III & & $(100) 7$ & $(100) 4$ & $(100) 2$ & $(100) 0$ & $(100) 2$ & 3 \\
\hline I & & $(100) 6$ & $(100) 4$ & $(100) 3$ & $(100) 3$ & $(100) 0$ & 3 \\
\hline II & 12,5 & $(100) 8$ & $(100) 4$ & $(100) 3$ & $(100) 0$ & $(100) 0$ & 3 \\
\hline III & & $(100) 6$ & $(100) 8$ & $(100) 1$ & $(100) 1$ & $(100) 0$ & 3 \\
\hline I & & $(100) 5$ & $(100) 2$ & $(100) 2$ & $(100) 0$ & $(100) 0$ & 2 \\
\hline II & 25 & $(100) 4$ & $(100) 2$ & $(100) 1$ & $(100) 1$ & $(100) 0$ & 2 \\
\hline III & & $(100) 4$ & $(100) 4$ & $(100) 1$ & $(100) 1$ & $(100) 0$ & 2 \\
\hline I & & $(100) 4$ & $(100) 2$ & $(100) 0$ & $(100) 0$ & $(100) 0$ & 1 \\
\hline II & 50 & $(100) 3$ & $(100) 2$ & $(100) 0$ & $(100) 0$ & $(100) 0$ & 1 \\
\hline III & & $(100) 3$ & $(100) 1$ & $(100) 0$ & $(100) 0$ & $(100) 0$ & 1 \\
\hline Kontrol & & $(100) 58$ & $(100) 34$ & $(100) 32$ & $(100) 30$ & $(100) 28$ & 36 \\
\hline
\end{tabular}

Keterangan : (100)= jumlah lalat uji (Chrysomya megacephala)

Berdasarkan tabel 1, dapat dilihat jumlah lalat hinggap pada ikan asin kontrol rerata sebanyak 36 ekor, angka terendah adalah 28 ekor lalat yaitu pada proses penjemuran pukul 16.00 WIB dan untuk nilai tertinggi adalah 58 ekor lalat pada penjemuran pukul 08.00 WIB.

Pada waktu proses penjemuran ikan asin menggunakan larutan daun cengkeh konsentrasi 1,56\% dari 3 kali pengulangan diperoleh nilai terendah 4 ekor lalat dan angka tertinggi adalah 18 ekor lalat, dengan rerata 8 ekor. Untuk konsentrasi 3,12\% nilai terendah jumlah lalat yang hinggap 2 ekor tertinggi 15 ekor dengan rerata 7 ekor. Pada konsentrasi $6,25 \%$ nilai terendah 0 ekor, tertinggi 8 ekor dengan rerata 4ekor. Konsentrasi $12,5 \%$ terendah 0 ekor tertinggi 8 ekor dengan rerata 3 ekor.
Konsentrasi $25 \%$ terendah 0 ekor tertinggi 5 rerata 2 ekor, dan konsentrasi 50\% terendah 0 ekor tertinggi 4 ekor dengan rerata 1 ekor.

Persentase rerata penurunan jumlah lalat yang hinggap pada ikan asin dengan variasi konsentrasi larutan Syzigium aromaticum selama 10 jam dengan menggunakan rumus dari komisi pestisida7) sebagai berikut :

Keterangan :

$$
(\mathrm{K}-\mathrm{R}) \mathrm{K} \times 100 \%
$$

DP = Daya Proteksi

$\mathrm{K}$ = Banyaknya lalat hinggap pada Ikan Asin Kontrol

$\mathrm{R}$ = Banyaknya lalat hinggap pada Ikan Asin Perlakuan

Tabel 2. Persentase Penurunan Jumlah Lalat Hijau Hinggap Pada Berbagai Konsentrasi Larutan Daun Cengkeh Selama Proses Penjemuran Ikan Asin

\begin{tabular}{cccccccc}
\hline \multirow{2}{*}{ Pengulangan ke-- Konsentrasi larutan Syzigium aromaticum } \\
\cline { 2 - 7 } & Kontrol & $1,56 \%$ & $3,12 \%$ & $6,25 \%$ & $12,5 \%$ & $25 \%$ & $50 \%$ \\
\hline I & & $9(75,0)$ & $6(83,3)$ & $5(86,1)$ & $3(91,6)$ & $2(94,4)$ & $1(97,2)$ \\
II & 36 & $7(80,5)$ & $7(80,5)$ & $4(88,8)$ & $3(91,6)$ & $2(94,4)$ & $1(97,2)$ \\
III & & $8(77,7)$ & $7(80,5)$ & $3(91,6)$ & $3(91,6)$ & $2(94,4)$ & $1(97,2)$ \\
\hline Rata-rata & 36 & $8(77,7)$ & $7(80,5)$ & $4(88,8)$ & $3(91,6)$ & $2(94,4)$ & $1(97,2)$ \\
\hline
\end{tabular}

Berdasarkan tabel 2, dapat dilihat bahwa persentase rata-rata penurunan jumlah lalat yang hinggap pada ikan asin dengan konsentrasi $1,56 \%$ adalah $77,7 \%$, rata-rata penurunan jumlah lalat hinggap pada konsentrasi $3,12 \%$ adalah $80,5 \%$, rata-rata penurunan jumlah lalat hinggap pada konsentrasi $6,25 \%$ adalah $88,8 \%$, rata- 
rata penurunan jumlah lalat hinggap pada konsentrasi $12,5 \%$ adalah $91,6 \%$, rata-rata penurunan jumlah lalat hinggap pada Hasil uji anova konsentrasi $25 \%$ adalah $94,4 \%$, rata-rata penurunan jumlah lalat hinggap pada konsentrasi $50 \%$ adalah $97,2 \%$.

Tabel 3. Distribusi rerata Jumlah Lalat Hinggap Selama Proses Penjemuran Ikan Asin Berdasarkan variasi Konsentrasi Larutan Daun Cengkeh

\begin{tabular}{lcccc}
\hline \multicolumn{1}{c}{ Variabel } & Mean & SD & 95\% CI & Nilai P \\
\hline Konsentrasi 0\% & 36,00 & 0,000 & $36,00-36,00$ & \\
Konsentrasi 1,56\% & 8,00 & 1,000 & $5,52-10,48$ & \\
Konsentrasi 3,12 \% & 6,67 & 0,577 & $5,23-8,10$ & 0,000 \\
Konsentrasi 6,25 \% & 4,00 & 1,000 & $1,52-6,48$ & \\
Konsentrasi 12,5 \% & 3,00 & 0,000 & $3,00-3,00$ & \\
Konsentrasi 25 \% & 2,00 & 0,000 & $2,00-2,00$ & \\
Konsentrasi 50 \% & 1,00 & 0,000 & $1,00-1,00$ & \\
\hline
\end{tabular}

Pada tabel 3, rerata jumlah lalat yang hinggap pada konsentrasi $0 \%$ (kontrol) adalah 36,00 ekor dengan standar deviasi 0,00 ekor. Pada konsentrasi $1,56 \%$ rerata jumlah lalat yang hinggap 8,00 dengan standar deviasi 1,000 ekor. Konsentrasi $3,12 \%$ rata-rata jumlah lalat yang hinggap 6,67 ekor dengan Standar Deviasi 0,577.

Pada konsentrasi 6,25 \% rerata jumlah lalat yang hinggap 4,00 ekor dengan Standar Deviasi 1,000 ekor. Pada konsentrasi larutan daun cengkeh 12,5 \% rerata jumlah lalat yang hinggap 3,00 ekor dengan Standar Deviasi 0,000. Pada konsentrasi $25 \%$ rerata jumlah lalat yang hinggap 2,00 ekor dengan Standar Deviasi 0,000. Pada konsentrasi $50 \%$ rerata jumlah lalat yang hinggap 1,00 ekor dengan Standar Deviasi 0,000 ekor.

Hasil uji statistik diperoleh nilai $p=0,000$. Bearati pada alpha $5 \%$, dapat disimpulkan ada perbedaan konsentrasi larutan daun cengkeh terhadap penurunan jumlah lalat yang hinggap selama proses penjemuran ikan asin.

Untuk mengetahui konsentrasi yang paling efektif maka dilakukan Uji Post Hoc dengan menggunakan Least Significant Difference (LSD).

Tabel 4. Hasil Uji Post Hoc Multiple Comparison Rerata Jumlah Lalat Hinggap Pada Ikan Asin Selama Proses Penjemuran Berdasarkan Konsentrasi Larutan Daun Cengkeh

\begin{tabular}{cccc}
\hline Kelompok Konsentrasi & Mean Difference & Nilai P \\
\hline \multirow{2}{*}{$\mathbf{0 \%}$} & $3,56 \%$ & $-28,000^{*}$ & 0,000 \\
& $6,12 \%$ & $29,333^{*}$ & 0,000 \\
& $12,5 \%$ & $32,000^{*}$ & 0,000 \\
$25 \%$ & $33,000^{*}$ & 0,000 \\
$50 \%$ & $34,000^{*}$ & 0,000 \\
& $3,12 \%$ & $35,000^{*}$ & 0,000 \\
\hline \multirow{2}{*}{$\mathbf{5 6} \%$} & $6,25 \%$ & $1,333^{*}$ & 0,013 \\
& $12,5 \%$ & $4,000^{*}$ & 0,000 \\
& $25 \%$ & $5,000^{*}$ & 0,000 \\
& $50 \%$ & $6,000^{*}$ & 0,000 \\
\end{tabular}




\begin{tabular}{cccc}
\hline Kelompok Konsentrasi & Mean Difference & Nilai P \\
\hline \multirow{3}{*}{$\mathbf{3 , 1 2} \%$} & $6,25 \%$ & $2,667^{*}$ & 0,000 \\
& $12,5 \%$ & $3,667^{*}$ & 0,000 \\
& $25 \%$ & $4,667^{*}$ & 0,000 \\
& $50 \%$ & $5,667^{*}$ & 0,000 \\
\hline \multirow{6}{*}{$\mathbf{2 5 \%}$} & $12,5 \%$ & 1,000 & 0,052 \\
& $25 \%$ & $2,000^{*}$ & 0,001 \\
$\mathbf{1 2 , 5 \%}$ & $50 \%$ & $3,000^{*}$ & 0,000 \\
& $25 \%$ & 1,000 & 0,052 \\
$\mathbf{2 5 \%}$ & $50 \%$ & $2,000^{*}$ & 0,001 \\
\hline
\end{tabular}

Pada tabel diatas menunjukkan bahwa hasil uji Post Hoc dengan LSD secara statistik semua kelompok konsentrasi larutan daun cengkeh memiliki pengaruh yang berbeda terhadap jumlah lalat hinggap pada proses penjemuran ikan asin karena nilai $\mathrm{P}<\alpha 5 \%$. Dengan melihat Mean Difference menunjukkan bahwa konsentrasi larutan daun cengkeh memiliki nilai Mean Difference lebih tinggi dibandingkan dengan $0 \%$ (Kontrol) dan konsentrasi larutan daun cengkeh 25\%, 12,5\%, 6,25\%, 3,12\% dan 1,56\%. Dengan demikian konsentrasi larutan daun cengkeh 50\% lebih berpengaruh dibandingkan dengan konsentrasi larutan daun cengkeh 25\%, $12,5 \%, 6,25 \%, 3,12 \%$ dan $1,56 \%$.

Hasil uji korelasi dan regresi. Untuk mengetahui hubungan antara berbagai konsentrasi larutan daun cengkeh dengan jumlah lalat hijau yang hinggap pada ikan asin digunakan uji korelasi, dimana Hasil uji terlihat bahwa nilai $(r)=-0,759$ sehingga hubungan dapat dikategorikan kuat. Sedangkan nilai $P$ diperoleh 0,048 sehingga ada hubungan antara konsentrasi larutan daun cengkeh dengan jumlah lalat hinggap pada ikan asin selama proses penjemuran ikan asin.

Tabel 5. Hasil Uji Korelasi

\begin{tabular}{lcc}
\hline \multicolumn{1}{c}{ Variabel } & r & Nilai P \\
\hline $\begin{array}{l}\text { Konsentrasi Larutan dan Jumlah Lalat Hijau } \\
\text { yang Hinggap }\end{array}$ & $-0,759^{*}$ & 0,048
\end{tabular}

Dari tabel diatas terlihat bahwa konsentrasi larutan daun cengkeh dan jumlah lalat hinggap mempunyai koefisien korelasi $(r)=-0,759$, dimana hubungan tersebut dapat dikategorikan kuat yang berpola negatif, artinya semakin tinggi konsentrasi semakin berkurang jumlah lalat yang hinggap pada ikan asin.
Dari uji statistik pada taraf kepercayaan $5 \%$ terdapat hubungan yang bermakna antara konsentrasi larutan dan jumlah lalat yang hinggap Untuk melihat bentuk hubungan dua variabel independen dan dependen juga dapat membuat model matematika untuk melakukan prediksi (perkiraan) nilai suatu variabel dependen dari variabel independen dengan membuat persamaan garis (garis regresi) : $y=a+b x$.

Tabel 6. Hasil Uji Regresi

\begin{tabular}{ccccc}
\hline Variabel & $\mathbf{R}$ & $\mathbf{R}^{2}$ & Garis Regresi & $\begin{array}{c}\text { Nilai } \\
\mathbf{P}\end{array}$ \\
\hline $\begin{array}{c}\text { Konsentrasi Larutan dan Jumlah } \\
\text { Lalat Hinggap }\end{array}$ & - & 0,576 & Jumlah Lalat Hinggap $=4,162-0,133$ & 0,048 \\
& 0,759 & & (Konsentrasi) & \\
\hline
\end{tabular}


Pada Tabel diatas terlihat bahwa hubungan konsetrasi dan jumlah lalat hinggap berkategori hubungan kuat $(\mathrm{r}=$ 0,759 ) yang berpola linier negatif, artinya semakin tinggi konsentrasi yang digunakan menyebabkan turunnya jumlah lalat yang hinggap pada ikan asin. Sebesar 57,6\% Variabel jumlah lalat hinggap dapat dijelaskan antara variabel konsentrasi (Koef determinasi 57,6\%), namun dari hasil uji statistik di peroleh nilai $\mathrm{P}=0,048$ dengan demikian terdapat hubugan yang linier antara konsentrasi dan jumlah lalat hinggap. Sehingga di dapat rumus garis prediksi = $4,162+\{-0,133 \times($ konsentrasi X) $\}$.

\section{Pembahasan}

Minyak daun cengkih tergolong insektisida nabati, insektisida nabati mudah terurai di alam (biodegradable), sehingga tidak mencemari lingkungan, relatif aman bagi manusia dan hewan. Contoh insektisida nabati adalah tanaman cengkih yang mengandung eugenol. Eugenol merupakan senyawa fenol yang memiliki gugus alkohol sehingga dapat melemahkan dan mengganggu sistem saraf pada serangga(5).

Minyak cengkih bermanfaat sebagai insektisida terhadap serangga karena mengandung Eugenol, isoeugenol, dan metil eugenol bersifat racun kontak terhadap serangga, Oleh karena itu proses penjemuran ikan asin dengan dibubuhi beberapa konsentrasi larutan daun cengkeh yang tidak diketahui jumlah zat aktifnya mampu mengurangi jumlah lalat hinggap selama proses penjemuran ikan asin.

Dapat diamati aktivitas dan perilaku lalat sebelum menghinggapi suatu sampel yang dianggapnya sebagai makanan selama penelitian berlangsung. Berdasarkan hasil pengamatan, apabila seekor lalat ingin menghinggapi suatu sampel baik untuk makan ataupun bertelur, ia akan melakukan beradaptasi terlebih dahulu untuk memastikan apakah pada sampel tersebut terdapat bahan-bahan yang dapat merugikannya.

Lalat hanya hinggap sebentar dan langsung terbang meninggalkan suatu sampel apabila pada sampel tersebut terdapat bahan yang tidak disukainya. Lalat memiliki bagian yang sangat peka yaitu tarsi yang terletak pada bagian kepala dan thorax karena adanya kemoreseptor atau sensilia olfaktori yang berpori sehingga dapat mendeteksi aroma yang tidak disenangi. Pada umumnya serangga memiliki dendrit atau bagian cabang neuron yang berfungsi menerima rangsangan pada bagian ujung yang tidak terlindung(6).

Pada penelitian ini didapatkan hasil bahwa semakin tinggi konsentrasi larutan maka semakin kecil jumlah lalat hijau yang hinggap pada ikan asin namun pada konsentrasi $50 \%$ masih terdapat lalat yang hinggap yaitu rata-rata sebanyak 1 Ekor lalat/100 ekor lalat uji, atau daya proteksinya sebesar $97,2 \%$ pada saat rentang penjemuran pukul $08.00-10.00$ WIB. Hal ini bisa disebabkan oleh jumlah kandungan zat aktif yang tidak merata pada ikan asin, atau pada saat dilakukan penelitian cuaca tidak terlalu panas sehingga zat aktif pada larutan cengkeh belum bersinergi secara efektif dengan sinar matahari untuk membuat bau yang tidak disenangi lalat.

Berdasarkan pemeriksaan jumlah lalat hijau yang hinggap selama penelitian, proses penjemuran ikan asin dengan menggunakan beberapa konsentrasi larutan daun cengkeh berpengaruh terhadap jumlah lalat yang hinggap pada ikan asin yaitu pada kontrol rata-rata jumlah lalat yang hinggap adalah 36 ekor/ 100 ekor lalat sedangkan pada konsentrasi larutan sebesar 50\% dapat menurunkan rata-rata sebanyak $97,2 \%$ lalat hinggap, rata-rata jumlah lalat hinggap pada konsentrasi larutan sebesar $25 \%$ adalah $94,4 \%$, rata-rata jumlah lalat hinggap pada konsentrasi larutan sebesar $12,5 \%$ adalah $91,6 \%$, rata-rata jumlah lalat hinggap pada konsentrasi larutan sebesar $6,25 \%$ adalah $88,8 \%$, rata-rata jumlah lalat hinggap dari konsentrasi larutan sebesar $3,12 \%$ adalah $80,5 \%$, dan rata-rata jumlah lalat hinggap dari konsentrasi larutan sebesar $1,56 \%$ adalah $77,7 \%$.

Secara statistik dengan tingkat kemaknaan 95\% menyatakan bahwa Ho ditolak, yang berarti terdapat perbedaan pengaruh berbagai konsentrasi larutan daun cengkeh (Syzigium aromaticum) 
terhadap jumlah lalat hijau (Chrysomya megacephala) yang hinggap selama proses penjemuran ikan asin. Hal ini sejalan dengan teori bahwa daun cengkeh dapat dijadikan repplent nabati untuk mengusir serangga khususnya lalat karena kandungan euganol pada daun cengkeh yang tidak disenangi oleh indera penciuman lalat(2).

Hasil penelitian sebelumnya yang meneliti hal serupa dengan menggunakan ekstrak daun cengkeh yang dilaksanakan di
Kampung Kurnia Kelurahan Belawan Bahari dimana pada konsentrasi 12,5\% ekstrak daun cengkeh dapat menurunkan jumlah lalat yang hinggap pada proses penjemuran ikan asin. Dengan demikian mengacu pada penelitian tersebut tersirat bahwa semakin tinggi konsentrasi yang digunakan, maka semakin baik untuk mengurangi jumlah lalat yang hinggap pada ikan asin. Untuk lebih jelasnya, berikut merupakan grafik rata-rata jumlah lalat hinggap :

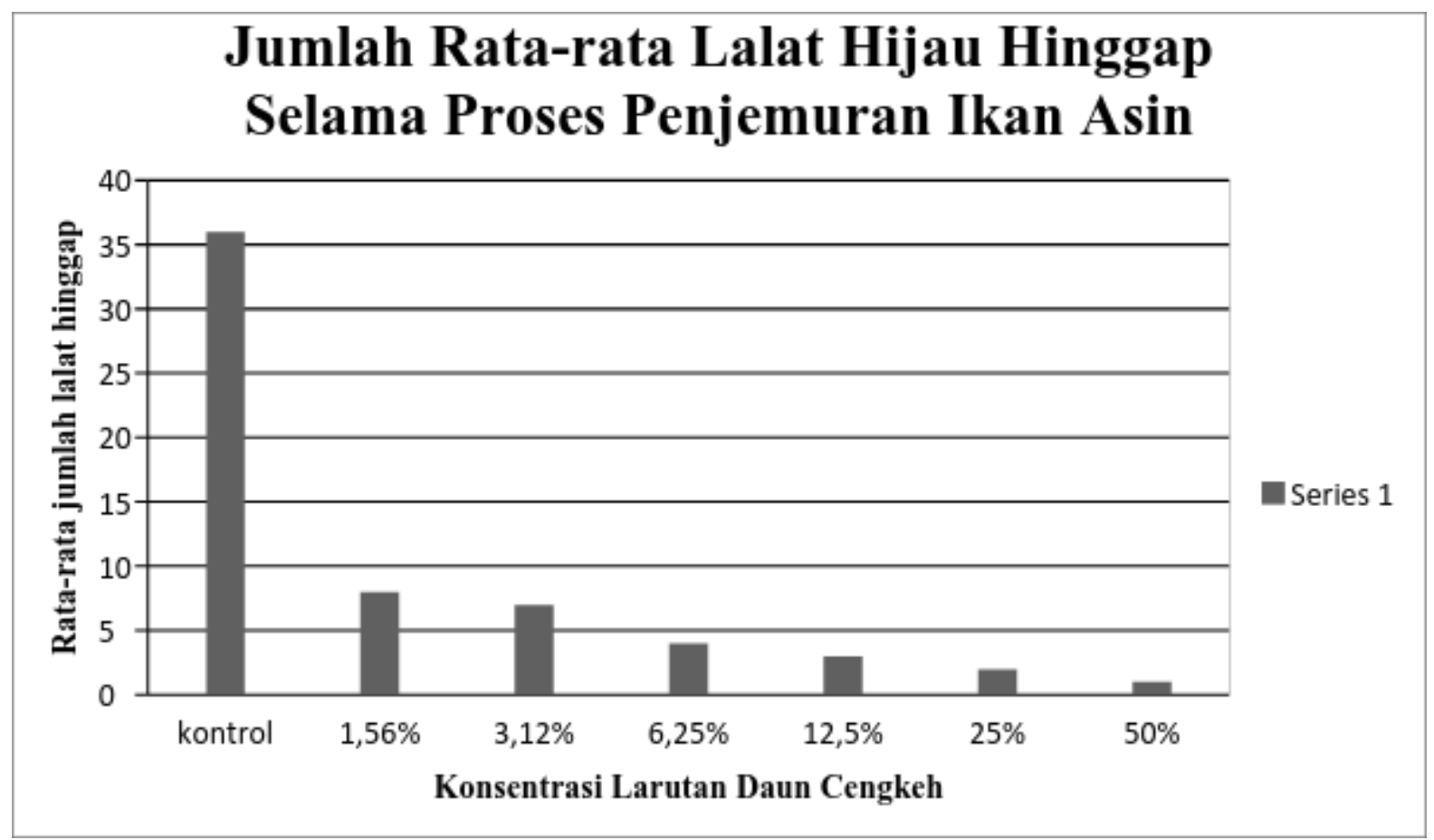

Gambar 1. Jumlah rata-rata lalat hijau hinggap selama proses penjemuran ikan asin

Dari gambar 1 dapat dilihat bahwa laju grafik semakin menurun. Semakin tinggi konsentrasi larutan yang digunakan maka semakin menurun jumlah lalat yang hinggap pada ikan asin, Hal ini disebabkan oleh efek sinergi antara sinar matahari dan Zat aktif pada larutan daun cengkeh dalam hal mengurangi jumlah lalat hinggap pada ikan asin.

Berdasarkan teori mengenai perilaku lalat tentang hal-hal yang mempengaruhi kehidupan lalat menyatakan bahwa Lalat mulai aktif beraktifitas pada temperatur 15 ${ }^{0} \mathrm{C}$ dan aktifitas optimumnya pada temperatur $21{ }^{\circ} \mathrm{C}$ dan Lalat sangat sensitif terhadap angin yang kencang, sehingga kurang aktif untuk keluar mencari makanan pada waktu kecepatan angin tinggi. Dalam proses penjemuran dilakukan di tempat terbuka dengan kondisi cuaca rata-rata sebesar $30,2{ }^{\circ} \mathrm{C}$, dalam konteks tersebut menyebabkan lalat terganggu oleh kondisi lingkungan yang tidak disenanginya ${ }^{(3)}$.

Berkurangnya jumlah lalat hinggap pada ikan asin ini tidak hanya disebabkan oleh konsentrasi larutan daun cengkeh tetapi juga dapat disebabkan karena suhu dan lingkungan yang diperlukan untuk kehidupan lalat khususnya pada saat mencari makan tidak dapat terpenuhi.

\section{KESIMPULAN}

1. Ada pengaruh konsentrasi larutan daun cengkeh (Syzigium aromaticum) terhadap jumlah lalat hijau (Chrysomya megacephala) yang hinggap selama proses penjemuran ikan asin dibuktikan dengan hasil uji Anova one 
way dengan derajat kepercayaan 95\% pada signifikasi 0,000 (P $<0,05)$. Dengan demikian Ho ditolak yaitu terdapat pengaruh yang bermakna secara statistik dari perlakuan berbagai konsentrasi larutan daun cengkeh terhadap jumlah lalat yang hinggap selama proses penjemuran ikan asin.

2. Hasil Uji Post Hoc dengan LSD menunjukkan bahwa Konsentrasi larutan daun cengkeh sebesar 50\% memiliki nilai $\mathrm{P}(0,000)<\alpha$ dan nilai Mean Difference lebih tinggi dibandingkan dengan konsentrasi yang lainnya. Dengan demikian konsentrasi larutan daun cengkeh sebesar 50\% lebih berpengaruh dibandingkan dengan konsentrasi lainnya.

3. Ada hubungan yang kuat berbagai konsentrasi larutan daun cengkeh terhadap jumlah lalat hijau yang hinggap selama proses penjemuran ikan asin dibuktikan dengan uji korelasi, koefisien korelasi ( $\mathrm{r}$ ) yang didapat adalah $-0,759$ yang berpola Linier negatif.

\section{SARAN}

1. Hasil penelitian ini diharapkan dapat menjadi alternatif pengendalian vektor yang bersifat alami dan tidak berbahaya bagi masyarakat.

2. Penggunaan Larutan daun cengkeh yang berlebihan dikhawatirkan akan mempengaruhi rasa pada ikan asin, oleh sebab itu perlu dilanjutkan penelitian mengenai uji organoleptik ikan asin yang telah dibubuhi berbagai konsentrasi larutan daun cengkeh.

3. Pengaplikasian metode ini dapat diterapkan khususnya di lingkungan yang memproduksi pembuatan ikan asin, dimana sebagai pengganti insektisida kimia dalam mengusir lalat daun cengkeh muda yang di blender kemudian direndam selama satu malam dapat dijadikan insektisida alami dalam mengusir atau mengurangi jumlah lalat yang hinggap pada ikan asin yang sedang dijemur, selain itu aman bagi lingkungan karena dapat di urai di alam berbeda dengan insektisida kimia yang sangat berbahaya bagi lingkungan karena tidak dapat terurai di alam. .

\section{KEPUSTAKAAN}

1. Sumatri, Arif. Kesehatan Lingkungan Edisi Revisi. Jakarta: Kencana Predana Media Group. 2013

2. Idriasih, Minar dkk. Pemanfaatan Ekstrak Daun Cengkeh (syzigium aromaticum) sebagai Reppelent Nabati dalam Mengurangi Jumlah Lalat yang Hinggap Selama Proses Penjemuran Ikan Asin. Jurnal: Fakultas Kesehatan Masyarakat. 2013

3. Singgih H S dkk. Hama Permukiman Indonesia Pengenalan, Biologi \& Pengendalian. Bogor: Intitut Pertanian Bogor. 2006

4. Jayanudin. Komposisi Minyak Atsiri Daun Cengkeh (Syzigium aromaticum) dari Proses Penyulingan Uap. Jurnal. 2011

5. Setyolaksono (BPPPTP Ambon). Serasah Daun Cengkeh yang Masih Bermanfaat. Artikel. Diakses tanggal 23 Januari 2014. dalam http//: ditjenbun.deptan.go.id

6. Kardinan, A. Daya Tolak Ekstrak Tanaman Rosemary (Rosmarinus officinalis) Terhadap Lalat Rumah (Musca domestica), Balai Penelitia Obat dan Aromatik. 2007 